\title{
Are similar the parasite communities structure of Trachelyopterus coriaceus and Trachelyopterus galeatus (Siluriformes: Auchenipteridae) in the Amazon basin?
}

São similares a estrutura das comunidades de parasitos de Trachelyopterus coriaceus e Trachelyopterus galeatus (Siluriformes: Auchenipteridae) na bacia amazônica?

Wanderson Michel de Farias Pantoja ${ }^{1}$; Lenise Vargas Flores Silva ${ }^{1}$; Marcos Tavares-Dias ${ }^{2 *}$

\begin{abstract}
${ }^{1}$ Programa de Pós-graduação em Recursos Aquáticos e Continentais Amazônicos - RACAM, Universidade Federal do Oeste do Pará - UFOPA, Santarém, PA, Brasil

${ }^{2}$ Laboratório de Sanidade de Organismos Aquáticos, Embrapa Amapá, Macapá, AP, Brasil
\end{abstract}

Received November 10, 2015

Accepted February 11, 2016

\begin{abstract}
The aim of this study was to compare the parasite communities in two sympatric host populations, Trachelyopterus coriaceus and Trachelyopterus galeatus, which were caught in tributary of the Amazon River in Brazil. All the specimens of T. galeatus and T. coriaceus were infected by one or more parasites, such as Ichthyophthirius multifliis, Tripartiella tetramerii, Trichodina nobilis, Cosmetocleithrum striatuli, Contracaecum sp., Cystidicoloides sp., Dadaytremoides parauchenipteri and Gorytocephalus spectabilis. Seven species were common to both host fish, and there were 1-5 parasite species per host. In both hosts, trichodinids were dominant. Aggregate dispersion of ectoparasites and endoparasites was observed, with greater aggregation among endoparasites. Only the ectoparasites species showed differences in intensity and/or abundance. However, the parasite communities of the two hosts were taxonomically similar (99\%) and characterized by high prevalence and high abundance of ectoparasites, but with low diversity, prevalence and abundance of endoparasites. Trachelyopterus galeatus, the host with the larger body size, presented greater variation of Brillouin diversity and evenness, while T. coriaceus had higher Berger-Parker dominance values and total numbers of parasites. This first study on these parasites of T. galeatus and T. coriaceus showed that the life mode, size of the hosts and the availability of infective forms of the parasites were the main factors that influenced the parasite communities structure.
\end{abstract}

Keywords: Amazon, auchenipterid, diversity, infection, parasites.

\section{Resumo}

O objetivo deste estudo foi comparar as comunidades, prevalência, intensidade, abundância e interaçóes parasito-hospedeiro em duas populaçóes de hospedeiros simpatricos, Trachelyopterus coriaceus e Trachelyopterus galeatus de um tributário do sistema do Rio Amazonas, no Brasil. Todos os espécimes de T. galeatus e T. coriaceus estavam infectados por um ou mais parasitos, tais como Ichthyophthirius multifiliis, Tripartiella tetramerii, Trichodina nobilis, Cosmetocleithrum striatuli, Contracaecum sp., Cystidicoloides sp., Dadaytremoides parauchenipteri e Gorytocephalus spectabilis. Sete espécies de parasitos foram comuns para ambos os peixes hospedeiros e houve de 1-5 espécies de parasitos por hospedeiro. Em ambos os hospedeiros houve dominância de espécies de tricodinídeos. A dispersão dos ectoparasitos e endoparasitos foi agregada, mas a maior agregação foi de endoparasitos. Somente espécies de ectoparasitos mostraram diferenças na intensidade e/ou abundância. Entretanto, as comunidades parasitárias dos dois hospedeiros foram taxonomicamente semelhante (99\%) e caracterizada por alta prevalência e abundância de ectoparasitos, mas com baixa diversidade, prevalência e abundância de endoparasitos. Trachelyopterus galeatus, com maior tamanho corporal, apresentou maior variação da diversidade Brillouin e uniformidade, enquanto T. coriaceus teve maiores valores de dominância de Berger-Parker e número total de parasitos. Este primeiro estudo sobre estes parasitos de T. galeatus e T. coriaceus mostrou que o modo de vida, tamanho dos hospedeiros e disponibilidade de formas infectantes de parasitos foram os principais fatores que influenciaram a estrutura das comunidades dos parasitos encontrados.

Palavras-chave: Amazônia, auchenipterídeo, diversidade, infecção, parasitos.

\footnotetext{
*Corresponding author: Marcos Tavares-Dias. Embrapa Amapá, Rodovia Juscelino Kubitschek, Km 5, 2600, CEP 68903-419, Macapá, AP, Brasil.

e-mail: marcos.tavares@embrapa.br
} 


\section{Introduction}

Auchenipteridae are Siluriformes with around 21 genera and 64 species distributed in freshwater rivers in South America, from Argentina to Panamá (BURGESS, 1989; FROESE \& PAULY, 2015). Most of these species have crepuscular or nocturnal habits, swimming frenetically close to the water surface in search of insects or other food items. During the daytime, they remain hidden in crevices or holes, or under tree trunks and branches. Trachelyopterus coriaceus Valenciennes, 1840, and Trachelyopterus galeatus Linnaeus, 1766, are congeneric phylogenetically related Auchenipteridae (BIRINDELLI, 2014) of small size that reach a maximum of $22 \mathrm{~cm}$, and reach sexual maturity at a length of around $11 \mathrm{~cm}$. Both of these fish species are found in wet areas of floodplains, and thus, T. galeatus and T. coriaceus are adapted to these hypoxic environments. The diet of Trachelyopterus spp. generally consists of insects, rotifers, mollusks and crustaceans (ANDRADE-LÓPEZ \& MACHADO-ALLISON, 2009; MESQUITA et al., 2011; FROESE \& PAULY, 2015). These two species of Trachelyopterus are not listed by the IUCN as endangered. Therefore, do these two siluriforms Auchenipteridae of the Amazon basin of Brazil have similar parasite communities structure?

The Igarapé Fortaleza basin is a singular ecosystem that is located in the eastern Amazon region of northern Brazil, and is an ecosystem highly influenced by the Amazon River system. It consists of linked fluvial physical systems that provide freshwater drainage, and is influenced by the high rainfall of the Amazon region and the daily tides of the Amazon River (GAMA \& HALBOTH, 2004; TAVARES-DIAS et al., 2013; BITTENCOURT et al., 2014a). The waters that periodically spread out across the floodplain are rich in nutrients, because of the rapid decomposition of grasses, animal remains and the humus layer of the forest. This leads to growth of new vegetation (Poaceae, Cyperaceae, Fabaceae, Onagraceae, Araceae, Asteraceae, Convolvulaceae and Lentibulariaceae) and invertebrate biomass (insects, zooplanktonic crustaceans and mollusks), which are used as food by fish (GAMA \& HALBOTH, 2004; TAKIYAMA et al., 2012), such as by T. galeatus and T. coriaceus. This ecosystem has been strongly influenced by eutrophication due to urbanization, as observed with regard to the parasite community of Curimata cyprinoides Linnaeus, 1766 (TAVARES-DIAS et al., 2013). Moreover, the Igarapé Fortaleza basin suffers a strong influence of invasion from Oreochromis niloticus, an exotic fish in Brazil (BITTENCOURT et al., 2014a). However, studies on parasite communities of T. galeatus and T. coriaceus has been not addressed.

In populations of wild fish, ectoparasites and endoparasites of different taxonomic groups can generally be found (LUNASCHI, 1989; TAKEMOTO \& LIZAMA, 2009; KOHN et al., 2011; MESQUITA et al., 2011; NEVES et al., 2013; TAVARESDIAS et al., 2013). The possibility of obtaining numerous repeats and quantifying the entirety of the parasite population distributed in different infection sites in fish facilitates detection of patterns within population dynamics, interspecies relationships and feeding relationships. These may reveal the potential that fish could have for participating as intermediate, paratenic or definitive hosts in the ecological systems of endohelminths (TAKEMOTO \& LIZAMA,
2009; MESQUITA et al., 2011; TAVARES-DIAS et al., 2013). However, the parasite community structure may be influenced by the environmental and a variety of other factors that relate mainly to the ecology and physiology of the host, seasonality, habitat quality and presence of larval stages of parasites in invertebrate transmitters (TAKEMOTO \& LIZAMA, 2009; KOHN et al., 2011; NEVES et al., 2013; TAVARES-DIAS et al., 2013).

In wild populations of T. galeatus of the Brazil, only the following helminths such 2 species of digeneans, 3 nematodes and 1 cestode are known (PAVANELLI \& SANTOS, 1990; FERNANDES \& KOHN, 2001; DIAS et al., 2006; TAKEMOTO \& LIZAMA, 2009; KOHN et al., 2011). In wild populations of T. galeatus of the Argentina, there have been reports only 2 species digeneans (LUNASCHI, 1989; LUNASCHI \& SUTTON, 1995). However, the parasite communities that T. galeatus and T. coriaceus harbor are still unknown and there are also no studies on their structure. In addition, given that these congeneric hosts present similar biological and behavioral characteristics and are phylogenetically close, this may favor the presence of similar parasite communities (GONZÁLEZ \& OLIVA, 2006; ALARCOS \& TIMI, 2012). Thus, the present study compared the parasite communities, prevalence, intensity, abundance and parasite-host interactions of $T$. galeatus and $T$. coriaceus living in sympatry in a tributary of the Amazon River system, northern Brazil.

\section{Materials and Methods}

\section{Fish and capture location}

Between September and December 2012, 37 specimens of $T$. galeatus and 35 specimens of $T$. coriaceus were caught in the Igarapé Fortaleza basin, tributary of the Amazon River system in the municipality of Macapá (state of Amapá), in northern Brazil, for parasitological analyses. All the fish were caught using hand nets and gillnets (15 to $25 \mathrm{~mm}$ ) and were transported alive to the Laboratory for Aquatic Organism Health at Embrapa Amapá (Macapá), for necropsy. This study was developed in accordance with the principles adopted by the Brazilian College of Animal Experimentation (Cobea).

\section{Parasites collection and analysis procedures}

The fish were weighed (g) and their lengths were measured $(\mathrm{cm})$. Following this, the gills and gastrointestinal tract were examined to ascertain whether any protozoan and metazoan parasites were present. All the parasites were collected, fixed, conserved, quantified and stained for identification (EIRAS et al., 2006). The ecological terms used were those recommended by Rohde et al. (1995) and Bush et al. (1997). Voucher specimens were deposited at the Scientific and Technological Research Institute of the State of Amapá (IEPA), in the Scientific Collection Curation Office for the Fauna of Amapá (CCFA), under accession number IEPA 033-043-P.

The Brillouin diversity index $(H B)$, richness of parasite species, evenness $(E)$ and Berger-Parker dominance index $(d)$ were calculated for each parasite infracommunity (MAGURRAN, 2004), using the 
Diversity software (Pisces Conservation Ltd, UK). The dispersion index (ID) and discrepancy index $(D)$ were calculated using the Quantitative Parasitology 3.0 software, in order to detect the distribution pattern of the parasite infracommunities (RÓZSA et al., 2000), for species with prevalence $>10 \%$. The significance of the ID, for each infracommunity, was tested using the $d$-statistic (LUDWIG \& REYNOLDS, 1988). Similarity in parasite communities between host populations was compared using the Jaccard index and Morisita index (LUDWIG \& REYNOLDS, 1988; MAGURRAN, 2004). Both similarity indices were calculated using the Past software (Paleontological Statistics version 3.0).

Body weight $(\mathrm{g})$ and total length $(\mathrm{cm})$ were used to calculate the relative condition factor $(\mathrm{Kn})$ of the fish using the length-weight relationship $\left(\mathrm{W}=\mathrm{aL}^{\mathrm{b}}\right)$ after logarithmic transformation of length and weight and subsequent adjustment of two straight lines, thus obtaining $\ln y=\ln \mathrm{A}+\mathrm{B} \ln x$ (LE-CREN, 1951).

\section{Data analyses}

To compare prevalence between T. galeatus and T. coriaceus, the chi-square test $\left(\chi^{2}\right)$ was used, followed by the Yates correction. The intensity, abundance, species richness, diversity $(H B)$, evenness $(E)$ and dominance $(d)$ were compared between the two hosts using the Mann-Whitney test $(U)$. The Shapiro-Wilk test was used to determine whether parasite abundance data followed a normal distribution pattern. Spearman's correlation coefficient $(r s)$ was used to determine possible correlations of the total length and body weight with parasites abundance, the Brillouin index $(H B)$ and the richness of parasite species (ZAR, 2010).

Principal component analysis (PCA) was carried out to compare the ways in which body and diversity influenced the parasite communities of T. galeatus and T. coriaceus. This analysis was performed using the Past software (Paleontological Statistics, version 3.0).

\section{Physical and chemical parameters of the water}

The mean temperature $\left(28.5 \pm 0.25^{\circ} \mathrm{C}\right)$, dissolved oxygen, $\mathrm{pH}(5.5 \pm 0.39)$, electrical conductivity $(0.15 \pm 0.17 \mu / \mathrm{cm})$, turbidity $(40.9 \pm 17.9$ UNT) and total dissolved solids $(0.02 \pm 0.0 \mathrm{~g} / \mathrm{L})$ were measured using a multiparameter probe (Horiba, model U-52). The ammonia level $(0.52 \pm 0.41 \mathrm{mg} / \mathrm{L})$, alkalinity $(26.6 \pm 5.7 \mathrm{mg} / \mathrm{L})$ and hardness $(23.3 \pm 5.7 \mathrm{mg} / \mathrm{L})$ were measured using a kit $\left(\right.$ Alfakit $\left.{ }^{\circledR}\right)$, and transparency $(31.8 \pm 13.5 \mathrm{~cm})$ was measured using a Secchi disc.

\section{Results}

All of the 72 specimens of $T$. galeatus and $T$. coriaceus examined were parasitized by one or more species. Species of Protozoa, Monogenoidea, Digenea and Nematoda were collected from both hosts. However, the dominant species were Tripartiella tetramerii Martins, Marchiori, Bittencourt \& Tavares-Dias, 2016 and Trichodina nobilis Chen, 1963 (Trichodinidae), followed by Ichthyophthirius multifiliis Fouquet, 1876 (Ichthyophthiriidae). Gorytocephalus spectabilis Machado, 1959 (Neoechinorhynchidae) was only found in the intestine of T. coriaceus (Table 1 ).

The prevalence $\left(\chi^{2}=3.657 ; \mathrm{p}=0.130\right)$ and mean abundance ( $U=494.5 ; \mathrm{p}=0.0001)$ of $I$. multifiliis were similar for T. coriaceus and T. galeatus, but the mean intensity $(U=287.5 ; \mathrm{p}=0.0002)$ was greater in $T$. galeatus. The prevalence $\left(\chi^{2}=5.083 ; \mathrm{p}=0.733\right)$ of T. tetramerii and T. nobilis was similar for $T$. coriaceus and $T$. galeatus, but the mean intensity $(U=278.0 ; \mathrm{p}=0.0004)$ and mean abundance $(U=278.0 ; \mathrm{p}=0.0001)$ were greater in T. coriaceus. Also in T. coriaceus, the prevalence $\left(\chi^{2}=6.192\right.$; $\mathrm{p}=0.039)$, mean intensity $(U=131.5 ; \mathrm{p}=0.0001)$ and mean abundance $(U=131.5 ; \mathrm{p}=0.0001)$ of Cosmetocleithrum striatuli Abdallah, Azevedo \& Luque, 2012 (Dactylogyridae) were greater than in T. galeatus.

The prevalence $\left(\chi^{2}=3.576 ; \mathrm{p}=0.1020\right)$, mean abundance $(U=527.0 ; \mathrm{p}=0.175)$ and mean intensity $(U=40.0 ; \mathrm{p}=0.378)$ of Dadaytremoides parauchenipteri Lunaschi, 1989 (Cladorchiidae) were similar for $T$. coriaceus and $T$. galeatus. The prevalence $\left(\chi^{2}=0.183 ; \mathrm{p}=0.9202\right)$, mean intensity $(U=20.5 ; \mathrm{p}=0.943)$ and mean abundance $(U=624.0 ; \mathrm{p}=0.791)$ of Contracaecum sp. were similar for $T$. coriaceus and $T$. galeatus. The prevalence $\left(\chi^{2}=6.00 ; \mathrm{p}=0.014\right)$ and mean abundance $(U=443.0 ; \mathrm{p}=0.021)$ of Cystidicoloides sp. were greater in T. galeatus than in T. coriaceus, but the mean intensity $(U=69.5 ; \mathrm{p}=0.334)$ was similar for the two hosts.

The parasite species in T. galeatus and T. coriaceus presented an aggregated distribution pattern (Table 2), which is a common pattern for freshwater fish.

The richness of parasite species in T. galeatus and T. coriaceus was similar, but the Brillouin diversity index and evenness were greater for T. galeatus, while the Berger-Parker dominance was greater

Table 1. Parasites of two Auchenipteridae fish in a tributary in the Amazon River system (Brazil).

\begin{tabular}{|c|c|c|c|c|c|c|c|c|c|c|}
\hline \multirow{2}{*}{$\begin{array}{c}\text { Host species } \\
\text { Parasite species }\end{array}$} & \multicolumn{5}{|c|}{ Trachelyopterus galeatus $(\mathrm{N}=37)$} & \multicolumn{5}{|c|}{ Trachelyopterus coriaceus $(\mathrm{N}=35)$} \\
\hline & $\mathbf{P}(\%)$ & MI & MA & FD (\%) & SI & $\mathbf{P}(\%)$ & MI & MA & FD (\%) & SI \\
\hline Ichthyophthirius multifiliis & 83.8 & 958.7 & 803.3 & 0.1186 & Gills & 97.1 & 636.0 & 617.9 & 0.0423 & Gills \\
\hline Tripartiella tetramerii and Trichodina nobilis & 86.5 & 6878.4 & 5948.9 & 0.8780 & Gills & 100 & 13894.4 & 13894.4 & 0.9512 & Gills \\
\hline Cosmetocleithrum striatuli & 83.8 & 23.2 & 19.4 & 0.0029 & Gills & 100 & 93.3 & 93.3 & 0.0064 & Gills \\
\hline Dadaytremoides parauchenipteri & 40.5 & 2.2 & 0.9 & - & Intestine & 20.0 & 3.3 & 0.7 & - & Intestine \\
\hline Contracaecum sp. (larvae) & 13.5 & 3.6 & 0.5 & - & Intestine & 17.1 & 2.5 & 0.4 & - & Intestine \\
\hline Cystidicoloides sp. (larvae) & 54.1 & 5.1 & 2.7 & 0.0004 & Intestine & 25.7 & 3.0 & 0.8 & - & Intestine \\
\hline Gorytocephalus spectabilis & 0 & 0 & 0 & 0 & - & 8.6 & 1.3 & 0.1 & - & Intestine \\
\hline
\end{tabular}

$\mathrm{P}=$ Prevalence; $\mathrm{MI}=$ Mean intensity; $\mathrm{SD}=$ Standard deviation; $\mathrm{MA}=$ Mean abundance; FD = Frequency of dominance; $\mathrm{SI}=$ Site of infection. 
for T. coriaceus (Table 3). In T. galeatus, the Brillouin index (HB) did not show any correlation with length $(r s=-0.235 ; \mathrm{p}=0.133)$ and weight ( $r s=-0.225 ; \mathrm{p}=0.153)$; nor did the parasite richness with the length $(r s=-0.154 ; \mathrm{p}=0.331)$ and weight $(r s=-0.098$; $\mathrm{p}=0.535)$. In $T$. coriaceus, the Brillouin index $(H B)$ did not show any correlation with the hosts' ( $r s=0.094 ; \mathrm{p}=0.552)$ and weight ( $r s=0.026 ; \mathrm{p}=0.869)$; nor did the parasite richness with the length ( $r s=-0.140 ; \mathrm{p}=0.375)$ and weight ( $r s=-0.106$; $\mathrm{p}=0.506)$. In both $T$. galeatus and T. coriaceus, the predominant level of parasitism was 3-4 species per host (Figure 1).
In $T$. coriaceus, the abundance of $T$. tetramerii, $T$. nobilis and $C$. striatuli showed a negative correlation with host length. In T. galeatus, the abundance of Tripartiella tetramerii presented a positive correlation with host length and weight, while the abundance of $C$. striatuli presented a negative correlation with host length (Table 4).

Principal component analysis based on the hosts' body and diversity parameters showed that for Brillouin diversity, evenness, species richness of parasites and Berger-Parker dominance were the main factor correlated with $T$. coriaceus and T. galeatus.

Table 2. Index of dispersion (ID), $d$-statistic, discrepancy index (D) and frequency of dominance (FD) for the infracommunities of parasites in species of Auchenipteridae in the Amazon River system (Brazil).

\begin{tabular}{|c|c|c|c|c|c|c|}
\hline \multirow{2}{*}{$\begin{array}{c}\text { Hosts } \\
\text { Parasites }\end{array}$} & \multicolumn{3}{|c|}{ Trachelyopterus galeatus } & \multicolumn{3}{|c|}{ Trachelyopterus coriaceus } \\
\hline & ID & $d$ & $\mathbf{D}$ & ID & $d$ & D \\
\hline Ichthyophthirius multifiliis & 2.366 & 4.65 & 0.359 & 2.103 & 3.85 & 0.317 \\
\hline Tripartiella sp. and Trichodina nobilis & 2.580 & 5.22 & 0.375 & 1.976 & 3.49 & 0.277 \\
\hline Cosmetocleithrum striatuli & 2.352 & 4.61 & 0.418 & 2.186 & 4.09 & 0.306 \\
\hline Dadaytremoides parauchenipteri & 1.702 & 2.66 & 0.677 & 2.360 & 4.56 & 0.826 \\
\hline Contracaecum sp. & 1.833 & 3.08 & 0.875 & 2.392 & 4.65 & 0.856 \\
\hline Cystidicoloides sp. & 3.461 & 7.38 & 0.659 & 2.638 & 5.29 & 0.810 \\
\hline
\end{tabular}

Table 3. Mean diversity indexes and body parameters \pm standard deviation and ranges (in parentheses) for the parasites community in Auchenipteridae species in the Amazon River system (Brazil). U: Mann-Whitney.

\begin{tabular}{|c|c|c|c|c|}
\hline Parameters & Trachelyopterus galeatus $(\mathrm{N}=37)$ & Trachelyopterus coriaceus $(\mathrm{N}=35)$ & $U$ & $p$ \\
\hline Body length & $10.8 \pm 2.0(7.5-14.5)$ & $9.3 \pm 1.5(6.6-13.5)$ & 364.0 & 0.001 \\
\hline Body weight & $20.1 \pm 13.2(4.0-52.0)$ & $10.7 \pm 7.1(4.0-42.0)$ & 354.5 & 0.001 \\
\hline Brillouin $(H B)$ & $0.32 \pm 0.16(0-0.65)$ & $0.26 \pm 0.12(0.03-0.56)$ & 433.0 & 0.016 \\
\hline Species richness & $3.62 \pm 0.92(1-5)$ & $3.69 \pm 0.80(2-5)$ & 643.5 & 0.964 \\
\hline Evenness $(E)$ & $0.18 \pm 0.09(0-0.38)$ & $0.12 \pm 0.06(0.01-0.29)$ & 460.0 & 0.015 \\
\hline Berger-Parker $(\mathrm{d})$ & $0.80 \pm 0.06(0.72-1.00)$ & $0.92 \pm 0.04(0.79-1.00)$ & 400.0 & 0.005 \\
\hline Total number of parasites & 250,700 & 511,261 & - & - \\
\hline Number of ectoparasites & 3 & 3 & - & - \\
\hline Number of endoparasites & 3 & 4 & - & - \\
\hline Endoparasites (adult) & 1 & 2 & - & - \\
\hline Endoparasites (larval) & 2 & 2 & - & - \\
\hline
\end{tabular}

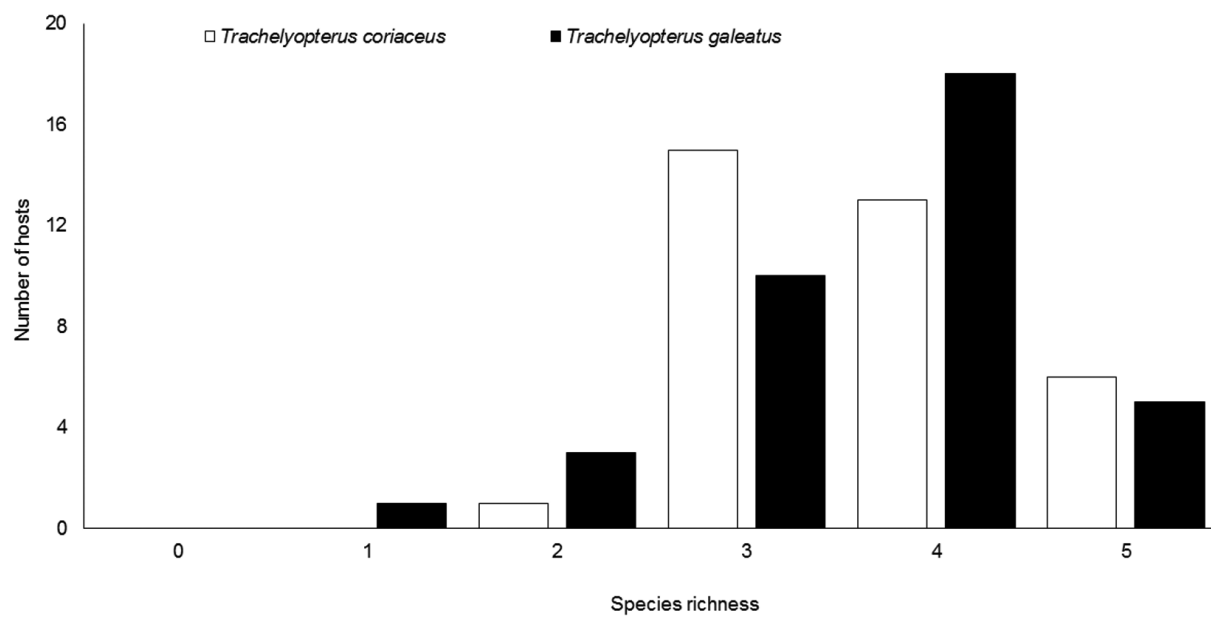

Figure 1. Species richness of parasites for species of Auchenipteridae in the Amazon River system (Brazil). 
The cumulative variance explained by the variables used was 83.9\% for both axes (Figure 2).

The Jaccard index $(\mathrm{J}=0.86)$ and Morisita index $(\mathrm{C} \lambda=0.99)$ demonstrated similarity between the parasite communities of $T$. coriaceus and $T$. galeatus. The multivariate analysis based on the component community of the parasites of $T$. coriaceus and
T. galeatus allowed observing that there is no separation among these hosts and only I. multifiliis was the species with least importance in this analysis (Figure 3).

For T. galeatus, the equation for the weight-length relationship was $\mathrm{Wt}=0.0034 \mathrm{Lt}^{3.5798}\left(\mathrm{r}^{2}=0.952\right)$; and for $T$. coriaceus, it was $\mathrm{Wt}=0.0091 \mathrm{Lt}^{3.1295}\left(\mathrm{r}^{2}=0.890\right)$. Thus, both of these relationships

Table 4. Spearman's correlation coefficient $(r s)$ for the abundance of parasites, in relation to the total length ( $\mathrm{cm}$ ) and body mass $(\mathrm{g})$ for species of Auchenipteridae in the Amazon river system (Brazil).

\begin{tabular}{|c|c|c|c|c|c|c|c|c|}
\hline \multirow{3}{*}{$\begin{array}{c}\text { Hosts } \\
\text { Parasites }\end{array}$} & \multicolumn{4}{|c|}{ Trachelyopterus galeatus $(\mathrm{N}=37)$} & \multicolumn{4}{|c|}{ Trachelyopterus coriaceus $(\mathrm{N}=35)$} \\
\hline & \multicolumn{2}{|c|}{ Total length } & \multicolumn{2}{|c|}{ Body weight } & \multicolumn{2}{|c|}{ Total length } & \multicolumn{2}{|c|}{ Body weight } \\
\hline & $r s$ & $\mathbf{p}$ & $r s$ & $\mathbf{p}$ & $r s$ & $\mathbf{p}$ & $r s$ & p \\
\hline Ichthyophthirius multifiliis & 0.2362 & 0.1593 & 0.2245 & 0.1815 & 0.0174 & 0.9186 & -0.0801 & 0.6376 \\
\hline Tripartiella sp. and Trichodina nobilis & 0.3258 & 0.0490 & 0.3784 & 0.0209 & -0.4429 & 0.0060 & -0.3223 & 0.0516 \\
\hline Cosmetocleithrum striatuli & -0.1980 & 0.02401 & -0.1589 & 0.3475 & -0.3403 & 0.0393 & -0.2375 & 0.1568 \\
\hline Dadaytremoides parauchenipteri & -0.2201 & 0.1905 & -0.1927 & 0.2530 & 0.2718 & 0.1035 & 0.3019 & 0.0693 \\
\hline Contracaecum sp. & 0.0669 & 0.6939 & 0.0534 & 0.7535 & 0.0873 & 0.6074 & 0.0367 & 0.8291 \\
\hline Cystidicoloides sp. & -0.0642 & 0.7058 & -0.0863 & 0.6117 & -0.0553 & 0.7452 & -0.1357 & 0.4231 \\
\hline
\end{tabular}

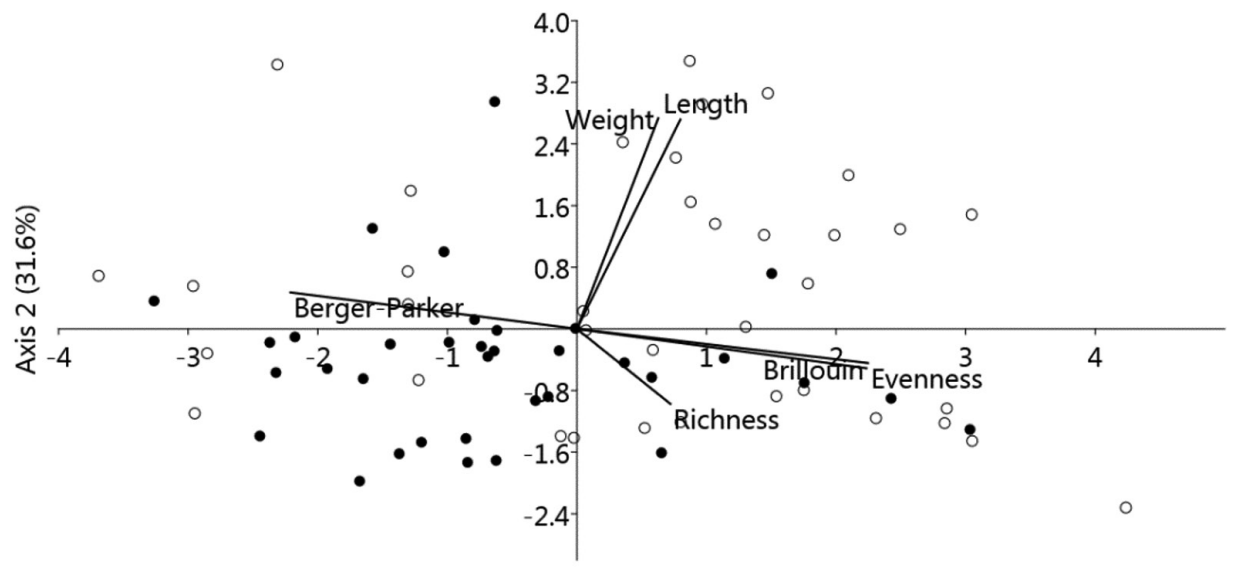

Axis $1(52.3 \%)$

Figure 2. Scatterplot scores from the principal component analysis (PCA) on factors influencing the parasites component communities of Trachelyopterus galeatus ( () and Trachelyopterus coriaceus $(\bullet)$ in the Amazon River system (Brazil).

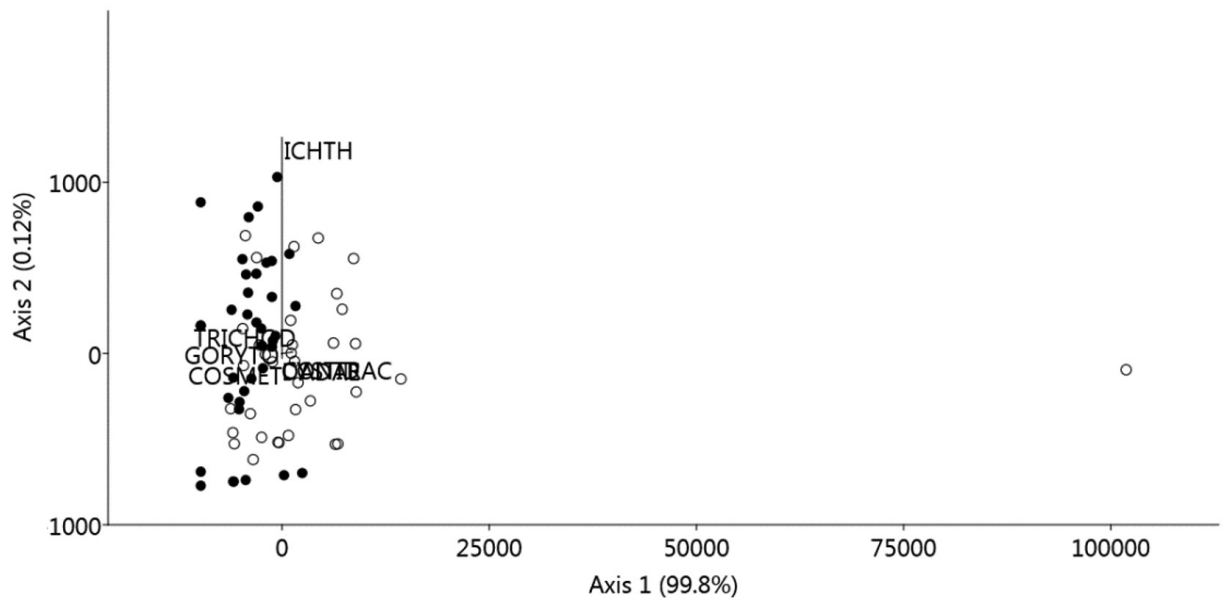

Figure 3. Scatterplot scores from the principal component analysis (PCA) of the parasites component communities of Trachelyopterus galeatus (०) and Trachelyopterus coriaceus $(\bullet)$ in the Amazon River system (Brazil). ICHTH: Ichthyophthirius multifliis, COSMET: Cosmetocleithrum striatuli, TRICHOD: Tripartiella sp. and Trichodina nobilis, DADAY: Dadaytremoides parauchenipteri, CONTRAC: Contracaecum sp., CYSTID: Cystidicoloides sp., GORYTO: Gorytocephalus spectabilis. 
were therefore allometrically positive, which indicates that there was greater increase in size than in body weight.

\section{Discussion}

For populations of $T$. galeatus of diverse localities in the Brazil, Microrchis oligovitellum Lunaschi, 1987; Clinostomum complanatum Rudolphi, 1814; Cangatiella arandasi; Contracaecum sp.; Goezia sp. and Cucullanellus sp. (PAVANELLI \& SANTOS, 1990; FERNANDES \& KOHN, 2001; DIAS et al., 2006; TAKEMOTO \& LIZAMA, 2009; KOHN et al., 2011) have been recorded. For wild populations of T. galeatus in Argentina, only Creptotrema creptotrema Travassos, Artigas and Pereira, 1928 and Dadaytremoides parauchenipteri Lunaschi, 1989 (LUNASCHI, 1989; LUNASCHI \& SUTTON, 1995) have been reported. However, among all these helminth species only Contracaecum larvae and $D$. parauchenipteri were also found on the hosts of this study.

This first study on the parasitic fauna of $T$. coriaceus and T. galeatus showed that they had similar richness of species and component community. Body size, diversity and evenness were greater for T. galeatus, but body size did not influence the diversity and richness of parasite species, in either of the two hosts. In these two hosts in the Amazon region, the dominant species were T. tetramerii and Trichodina nobilis, followed by I. multifiliis. These protozoans are typical of lentic-eutrophized environments like the hydrographic basin of this study (TAVARES-DIAS et al., 2013, 2014; BITTENCOURT et al., 2014b). In addition, in $T$. coriaceus and $T$. galeatus, the greatest richness of parasites was in species of helminths, with predominance of endoparasites of relatively high prevalence and low abundance, but only two endoparasites were found in larval stage (Contracaecum sp. and Cystidicoloides sp.). Several variables may influence the presence of endoparasites species, especially exposure to infective forms, which are directly acquired through the hosts' feeding (MOREIRA et al., 2009; TAKEMOTO \& LIZAMA, 2009; MESQUITA et al., 2011; TAVARES-DIAS et al., 2013). It is well known that the diet of the fish can be deduced from trophically transmitted parasites and because most endoparasites are associated with a specific ecological niche and diet, high diversity in host parasite fauna is often a result of a diverse host diet. Hence, a diverse parasitic communities of trophically transmitted parasites may indicate that the host population consumed a diversity of prey in habitat (WILSON \& HUBSCHMAN, 1985; MORAVEC, 2007; TARASCHEWSKI, 2008; MOREIRA et al., 2009; MORAVEC, 2009; NEVES et al., 2013; TAVARES-DIAS et al., 2013; BITTENCOURT et al., 2014b; TAVARES-DIAS et al., 2014).

The ectoparasites and endoparasites of T. coriaceus and T. galeatus presented aggregated dispersion, but endoparasites infections were the more aggregated. Aggregated dispersion patterns for ectoparasites and endoparasites have also been described in other freshwater hosts (MESQUITA et al., 2011; TAVARES-DIAS et al., 2014; AMARANTE et al., 2015), and these have been attributed to factors relating to the hosts, parasites and environment. These factors include formation of schools of fish, taxon in relation to sex, habitat, presence of parasite larvae, feeding habits and length of the hosts and the genetic and immune heterogeneity of the hosts (ROHDE et al., 1995; TAVARES-DIAS et al., 2014; AMARANTE et al., 2015).

The levels of infection due to I. multifiliis in T. coriaceus and T. galeatus were similar. This ectoparasite ciliate, which does not have parasitic specificity, occurs more frequently in fish in farmed environments, influenced by factors related to the parasite and host, and also by the physical and chemical characteristics of the water, such as dissolved oxygen levels, $\mathrm{pH}$, hardness, alkalinity and temperature (WEI et al., 2013; FORWOOD et al., 2015). However, this protozoon has wide geographic distribution and can parasitize fish on all continents. Severe infections may also cause mortality in populations of wild fish, because I. multifiliis has the capacity to reproduce rapidly (RAISSY et al., 2010; FORWOOD et al., 2015), when the environmental conditions are favorable. This was the first record of I. multifiliis for T. coriaceus and $T$. galeatus.

In $T$. coriaceus and $T$. galeatus, the prevalence of $T$. tetramerii and $T$. nobilis was similar for both hosts, but the intensity and abundance were higher in T. coriaceus. Moreover, the abundance of these trichodinids was higher in individuals of $T$. galeatus of greater size and was lower in individuals of $T$. coriaceus of greater length. In populations of wild fish, infections due to species of trichodinids are more frequent in environments that are eutrophized and have low oxygen levels (BASSON \& VAN AS, 2002; TAVARES-DIAS et al., 2014), like the Igarapé Fortaleza basin. This was the first record of T. tetramerii and T. nobilis for T. coriaceus and T. galeatus.

Cosmetocleithrum striatuli, a monogenoidean originally described in Trachelyopterus striatulus Steindachner, 1877, in the Guandu River, Southern Brazil region (ABDALLAH et al., 2012; SILVEIRA et al., 2013), showed a higher level of infection in adults of T. coriaceus than in subadults of T. galeatus, in the present study. These differences occurred because smaller and therefore younger individuals of $T$. coriaceus were more parasitized. In $T$. coriaceus, the abundance of $C$. striatuli showed a negative correlation with host length, while in $T$. galeatus the correlation was weak. These distinct results were due to differences in the host size. Thus, since $C$. striatuli was previously only known in T. striatulus (COHEN et al., 2013), the present paper provides the first report of this monogenoidean for T. galeatus and T. coriaceus.

Gorytocephalus spectabilis only parasitized T. coriaceus, and at low infection levels, which were similar to those reported for Aquidens tetramerus Heckel, 1840; Heros efasciatus Heckel, 1840; Chaetobranchus flavescens Heckel, 1840; and Satanoperca jurupari Heckel, 1840 - all these hosts were also from the ecosystem of this study (BITTENCOURT et al., 2014b; TAVARES-DIAS et al., 2014). Although congeneric host species have similar biological and behavioral characteristics and are therefore potential hosts for parasitic fauna that is also similar, closely related species may also exhibit divergent characteristics that allow them to coexist, such as in relation to some trophic traits (GUIDELLI et al., 2009). The absence of G. spectabilis in T. galeatus in this study indicates that despite the overlapping of living, feeding and environmental habits, this host did not have any contact with the infective forms of this endohelminth through trophic means. Species of Neoechinorhynchidae in freshwater fish have life cycles involving a definitive host and an intermediate host, which may be arthropods (amphipods, ostracods, isopods or copepods). However, some 
species have fish species as paratenic or definitive host, when they ingest an invertebrate that is an intermediate host or a small fish that serves as a paratenic host (WILSON \& HUBSCHMAN, 1985; TARASCHEWSKI, 2008). Despite the low abundance of $G$. spectabilis in $T$. coriaceus and $T$. galeatus, these fish seem to be definitive hosts in the environment studied here. This was the first record of $G$. spectabilis for $T$. coriaceus and $T$. galeatus.

Trachelyopterus coriaceus and T. galeatus showed similar low levels of infection by larvae of Contracaecum sp. These larvae are anisakid with parasitic specificity and, during their larval stage; their primary hosts are microcrustaceans (MORAVEC, 2009; MOREIRA et al., 2009). In the adult phase, piscivorous birds are their definitive hosts and fish are paratenic hosts (MORAVEC, 2009). The levels of infection due to larvae of Cystidicoloides sp. were higher in T. galeatus than in T. coriaceus, thus indicating that T. galeatus had greater contact with the infective forms of this endohelminth. In Brazil, only Cystidicoloides fischeri Travassos, Artigas and Pereira, 1928, and Cystidicoloides izecksohni Fabio, 1982, are known to parasitize different species of fish (LUQUE et al., 2011). For Cystidicolidae, species of crustaceans are the intermediate hosts and fish are paratenic or definitive hosts during their life cycle. However, the adult forms of these parasites occur in adult piscivorous fish, which are the definitive hosts (MORAVEC, 2007). Therefore, the presence of larvae of Cystidicoloides sp. indicates that adults of $T$. coriaceus and subadults of $T$. galeatus are paratenic hosts for this nematode in the ecosystem of this study.

Dadaytremoides parauchenipteri, a digenean that was originally described in T. galeatus from Argentina (LUNASCHI, 1989), showed similar levels of infection for T. coriaceus and T. galeatus in the present study. This species of Cladorchiidae had not previously been reported as parasitizing other species of fish in South America (KOHN et al., 2007) and therefore this was the first record of D. parauchenipteri in Brazil. Moreover, this endoparasite seems to have wide geographic distribution and primary association with species of siluriform Auchenipteridae. Although the life history of D. parauchenipteri is unknown, Thatcher \& Jégu (1996) stated that species of Cladorchiidae have a life cycle in which cercariae are released from infected snails and, through encysting on aquatic vegetation, form metacercariae that are then consumed by host fish. Given that in the ecosystem of this study, T. coriaceus and T. galeatus live close to aquatic vegetation; this favors encounters between these hosts and metacercariae, i.e. the infective forms of D. parauchenipteri. Therefore, T. coriaceus and T. galeatus are definitive hosts for this endohelminth, in the environment investigated here.

In summary, the richness of endoparasites with a complex life cycle in T. coriaceus and T. galeatus indicates that in the environment that these fish inhabit, their diet consists mainly of molluskand crustacean species. The size and behavior of these hosts, richness of parasites and availability of infective forms of intermediate hosts that make up the diet of these Siluriformes were the main factors influencing similar parasite communities. The parasite communities of these Amazonian hosts were characterized by high prevalence and high abundance of ectoparasites, but with low diversity, prevalence and abundance of endoparasites. Furthermore, the phylogenetic and taxonomic proximity of the hosts was also a strong influence on the parasite species, once the parasite communities of these two hosts were taxonomically similar (99\%). Finally, the external and internal host environment influenced the few differences in prevalence, intensity and abundance of parasites.

\section{Acknowledgements}

M. Tavares-Dias was supported by research fellowships from the Conselho Nacional de Pesquisa e Desenvolvimento Tecnológico (CNPq, Brazil).

\section{References}

Abdallah VD, Azevedo RK, Luque JLF. Three new species of Monogenea (Platyhelminthes) parasites of fish in the Guandu River, southeastern Brazil. Acta Sci Biol Sci 2012; 34(4): 483-490. http://dx.doi.org/10.4025/ actascibiolsci.v34i4.10466.

Alarcos AJ, Timi JT. Parasite communities in three sympatric flounder species (Pleuronectiformes: Paralichthyidae): similar ecological filters driving toward repeatable assemblages. Parasitol Res 2012; 110(6): 2155 2166. http://dx.doi.org/10.1007/s00436-011-2741-5. PMid:22167375.

Amarante CF, Tassinari WS, Luque JL, Pereira MJS. Factors associated with parasite aggregation levels in fishes from Brazil. Braz J Vet Parasitol 2015; 24(2): 174-182. http://dx.doi.org/10.1590/S1984-29612015031. PMid:26083693.

Andrade-López J, Machado-Allison A. Aspectos morfológicos y ecológicos de las especies de Heptapteridae y Auchenipteridae presentes en el Morichal Nicolasito (Rio Aguaro, Estado Guárico, Venezuela). Bol Acad C Fis Mat Nat 2009; 69(3): 35-52.

Basson L, Van As JG. Trichodinid ectoparasites (Ciliophora: Peritrichia) of freshwater fishes of the family Anabantidae from the Okavango River and Delta (Botswana). Folia Parasitol 2002; 49(3): 169-181. http://dx.doi. org/10.14411/fp.2002.032. PMid:12418809.

Birindelli JLO. Phylogenetic relationships of the South American Doradoidea (Ostariophysi: Siluriformes). Neotrop Ichthyol 2014; 12(3): 451-564. http://dx.doi.org/10.1590/1982-0224-20120027.

Bittencourt LS, Dias MT, Silva URL, Silva LMA. Impact of the invasion from Nile tilapia on natives Cichlidae species in tributary of Amazonas River, Brazil. Biota Amaz 2014a; 4(3): 88-94. http://dx.doi. org/10.18561/2179-5746/biotaamazonia.v4n3p88-94.

Bittencourt LS, Pinheiro DA, Cárdenas MQ, Fernandes BMM, TavaresDias M. Parasites of native Cichlidae populations and invasive Oreochromis niloticus in tributary of Amazonas River (Brazil). Braz J Vet Parasitol 2014b; 23(1): 44-54. http://dx.doi.org/10.1590/S1984-29612014006. PMid:24728360.

Burgess WE. An atlas of freshwater and marine catfishes: a preliminary survey of the Siluriformes. New York: T.F.H. Publications; 1989.

Bush AO, Lafferty KD, Lotz JM, Shostak AW. Parasitology meets ecology on its own terms: Margolis et al. revisited. J Parasitol 1997; 83(4): 575 583. http://dx.doi.org/10.2307/3284227. PMid:9267395.

Cohen SC, Justo MCN, Kohn A. South American Monogenoidea parasites offishes, amphibians and reptiles. Rio de Janeiro: Oficina de Livros; 2013.

Dias MLGG, Minte-Vera JC, Eiras JC, Machado MH, Souza GTR, Pavanelli GC. Ecology of Clinostomum complanatum Rudolphi, 1814 (Trematoda: Clinostomidae) infecting fish from the floodplain of the high Paraná River, Brazil. Parasitol Res 2006; 99(6): 675-681. http:// dx.doi.org/10.1007/s00436-006-0205-0. PMid:16738894. 
Eiras JC, Takemoto RM, Pavanelli GC. Métodos de estudo e técnicas laboratoriais em parasitologia de peixes. 2nd ed. Maringá: Eduem; 2006.

Fernandes BMM, Kohn A. On some trematodes parasites of fishes from Paraná River. BrazJ Biol2001; 61(3): 461-466. http://dx.doi.org/10.1590/ S1519-69842001000300016. PMid:11706574.

Forwood JM, Harris JO, Landos M, Deveney MR. Life cycle and settlement of an Australian isolate of Ichthyophthirius multifliis Fouquet, 1876 from rainbow trout. Folia Parasitol 2015; 62. http://dx.doi.org/10.14411/ fp.2015.013. PMid:25960557.

Froese R, Pauly D. FishBase. Version (02/2015) [online] 2015 [cited 2015 June]. Available from: http://www.fishbase.se/summary/Trachelyopteruscoriaceus.html

Gama CS, Halboth DA. Ictiofauna das ressacas das bacias do Igarapé da Fortaleza e do Rio Curiaú. In: Takiyama LR, Silva AQ. Diagnóstico das ressacas do Estado do Amapá: bacias do Igarapé da Fortaleza e Rio Curiaú, Macapá-AP. Macapá: CPAQ/IEPA, DGEO/SEMA; 2004. p. 23-52.

González MT, Oliva ME. Similarity and structure of the ectoparasite communities of rockfish species from the southern Chilean coast in a temporal scale. Parasitology 2006; 133(3): 335-343. http://dx.doi. org/10.1017/S0031182006000370. PMid:16753080.

Guidelli G, Takemoto RM, Pavanelli GC. Ecologia das infrapopulaçôes ectoparasitas das cavidades nasais de Leporinus lacustris (Anostomidae) da planície de inundaçáo do alto Rio Paraná. Acta Sci Biol Sci 2009; 31(2): 209-214. http://dx.doi.org/10.4025/actascibiolsci.v31i2.3309.

Kohn A, Fernandes BMM, Cohen SC, editors. South American trematodes parasites of fishes. Rio de Janeiro: Imprinta; 2007.

Kohn A, Moravec F, Cohen SC, Canzi C, Takemoto RM, Fernandes BMM. Helminths of freshwater fishes in the reservoir of the Hydroelectric Power Station of Itaipu, Paraná, Brazil. Check List 2011; 7(5): 681-690.

Le-Cren ED. The length-weight relationship and seasonal cycle in gonad weight and condition in the perch (Perca fluviatilis). J Anim Ecol 1951; 20(2): 201-219. http://dx.doi.org/10.2307/1540.

Ludwig JA, Reynolds JF. Statistical ecology: a primer on methods and computing. New York: Wiley-Interscience; 1988.

Lunaschi LI, Sutton CA. Sobre algunos digeneos parásitos del peces del canal Irigoyen Isla Talavera, Provincia de Buenos Aires. Neotropica 1995; 41: 99-104.

Lunaschi LI. Helmintos parásitos de peces de agua dulce de la argentina. VII. Acerca de dos nuevas especies de paranfistómidos (Trematoda -Paramphistomidae). Neotropica 1989; 35(93): 35-42.

Luque JL, Aguiar JC, Vieira FM, Gibson DI, Portes-Santos C. Checklist of Nematoda associated with the fishes of Brazil. Zootaxa 2011; 3082: 1-88.

Magurran AE. Measuring biological diversity. Oxford: Blackwell Science; 2004 .

Mesquita RLB, Azevedo RK, Abdallah VD, Luque JL. Ectoparasites as numerical dominant species in parasite community of Trachelyopterus striatulus (Siluriformes: Auchenipteridae) from Guandu River, southeastern Brazil. Braz J Biol 2011; 71(3): 623-627. PMid:21881785.

Moravec F. Experimental studies on the development of Contracaecum rudolphii (Nematoda: Anisakidae) in copepod and fish paratenic hosts. Folia Parasitol (Praha) 2009; 56(3): 185-193. http://dx.doi.org/10.14411/ fp.2009.023. PMid:19827362.

Moravec F. Some aspects of the taxonomy and biology of adult spirurine nematodes parasitic in fishes: a review. Folia Parasitol (Praha) 2007; 54(4): 239-257. http://dx.doi.org/10.14411/fp.2007.033. PMid:18303766.
Moreira LHA, Takemoto RM, Yamada FH, Ceschini TL, Pavanelli GC. Ecological aspects of metazoan endoparasites of Metynnis lippincottianus (Cope, 1870) (Characidae) from upper Paraná River floodplain, Brazil. Helminthologia 2009; 46(4): 214-219. http://dx.doi.org/10.2478/ s11687-009-0040-9.

Neves LR, Pereira FB, Tavares-Dias M, Luque JL. Seasonal influence on the parasite fauna of a wild population of Astronotus ocellatus (Perciformes: Cichlidae) from the Brazilian Amazon. J Parasitol 2013; 99(4): 718-721. http://dx.doi.org/10.1645/12-84.1. PMid:23421456.

Pavanelli GC, Santos MHM. Cangatiella arandasi, gen. n. sp. n. (CestodaProteocephalidae), parasito de Parauchenipterus galeatus (Siluriformes Auchenipteridae) do Rio Paraná, PR. Rev Bras Zool 1990; 7(4): 535-539. http://dx.doi.org/10.1590/S0101-81751990000400012.

Raissy M, Ansari M, Moumeni M, Goudarzi MA, Sohrabi HR, Rashedi M. An epizootic of Ichthyophthiriasis among fishes in Armand River, Iran. J Cell Anim Biol 2010; 4(10): 151-153.

Rohde K, Hayward C, Heap M. Aspects of the ecology of metazoan ectoparasites of marine fishes. Int J Parasitol 1995; 25(8): 945-970. http://dx.doi.org/10.1016/0020-7519(95)00015-T. PMid:8550295.

Rózsa L, Reiczigel J, Majoros G. Quantifying parasites in samples of hosts. J Parasitol 2000; 86(2): 228-232. http://dx.doi.org/10.1645/00223395(2000)086[0228:QPISOH]2.0.CO;2. PMid:10780537.

Silveira ACA, Almeida KSS, Cohen SC. Estudo sobre a ocorrência de helmintos Monogenea, Digenea e Nematoda parasitando peixes da espécie Trachelyopterus striatulus (Steindachner, 1877) (Siluriformes: Auchenipteridae) provenientes do Rio Guandu (RJ). Saúde \& Amb Rev 2013; 8(1): 1-8.

Takemoto RM, Lizama M. Helminth fauna of fishes from the upper Paraná river floodplain, Brazil. Neotrop Helminthol 2009; 4(1): 5-8.

Takiyama LR, Silva URL, Jimenez EA, Pereira RA, Zacardi DM, Fernandes EF, et al. Zoneamento ecológico econômico urbano das áreas de ressacas de Macapá e Santana, Estado do Amapá. Macapá: IEPA; 2012.

Taraschewski H. Acanthocephala. In: Eiras JC, Segner H, Wahli T, Kapoor BG. Fish diseases. Enfield: Science Publishers; 2008. p. 1025-1062.

Tavares-Dias M, Neves LR, Pinheiro DA, Oliveira MSB, Marinho RGB. Parasites in Curimata cyprinoides (Characiformes: Curimatidae) from eastern Amazon, Brazil. Acta Sci Biol Sci 2013; 35(4): 595-601. http:// dx.doi.org/10.4025/actascibiolsci.v35i4.19649.

Tavares-Dias M, Oliveira MSB, Gonçalves RA, Silva LM. Ecology and seasonal variation of parasites in wild Aequidens tetramerus, a Cichlidae from the Amazon. Acta Parasitol 2014; 59(1): 158-164. http://dx.doi. org/10.2478/s11686-014-0225-3. PMid:24570063.

Thatcher EV, Jegú M. Intestinal helminths as population markers of the Amazonian fish Mylesinus paraschomburgkii, with descriptions of five new genera and seven new species of trematodes. Amazoniana 1996; 14(1-2): 145-155.

Wei JZ, Li H, Yu H. Ichthyophthiriasis: emphases on the epizootiology. Lett Appl Microbiol 2013; 57(2): 91-101. http://dx.doi.org/10.1111/ lam.12079. PMid:23565747.

Wilson BA, Hubschman JH. Host-parasite relationships of Tanaorhamphus longirostris (Acanthocephala: Neochinorhynchidae) in the Intermediate host, Diaptomus pallidus (Crustacea: Copepoda). J Helminthol Soc Wash 1985; 52(1): 71-75.

Zar JH. Biostatistical analysis. 5th ed. New Jersey: Prentice Hall; 2010. 